\title{
Gynaecologic History During Adolescence to Predict Endometriosis Earlier Hartati $^{1}$, Yusuf Effendi ${ }^{1}$, Dwiana Ocviyanti ${ }^{2}$, Ramzi Amin $^{3}$, Zen Hafy ${ }^{4}$, Radiyati Umi Partan ${ }^{5}$, Rafika Novianti ${ }^{*}$
}

${ }^{1}$ Department of Obstetrics and Gynecology, Faculty of Medicine, Universitas Sriwijaya, Palembang, Indonesia

2 Department of Obstetrics and Gynecology, Faculty of Medicine, Universitas Indonesia, Jakarta, Indonesia

${ }^{3}$ Department of Opthamology, Faculty of Medicine, Universitas Sriwijaya, Palembang, Indonesia

4 Department of Histology, Faculty of Medicine, Universitas Sriwijaya, Palembang, Indonesia

${ }^{5}$ Department of Internal Medicine, Faculty of Medicine, Universitas Sriwijaya, Palembang, Indonesia

${ }^{6}$ Siloam Clinic Jakabaring, Palembang, Indonesia

\section{A R T I C L E I N F O \\ Keywords: \\ Endometriosis \\ Adolescence \\ Screening \\ Cost-effective \\ *Corresponding author: \\ Rafika Novianti \\ E-mail address: \\ rafikanovianti.md@gmail.com}

All authors have reviewed and approved the final version of the manuscript.

https://doi.org/10.37275/bsm.v6i3.465

\begin{abstract}
A B S T R A C T
Background. Endometriosis is a chronic gynecological disorder that generally affects women of reproductive age which is characterized by implantation of endometrial tissue, both glands and stroma outside the uterus. Research shows that the initial onset of endometriosis patients begins in adolescence. The high prevalence with atypical symptoms leads to long term delay in establishing the appropriate diagnosis. Further developments in the field of early endometriosis screening will greatly assist clinicians, especially general practitioners in areas with limited health facilities, in early detection of endometriosis. Methods: Using the electronic databases, comprehensive literature searches were conducted with the specific keywords. Full-text manuscripts published were reviewed for relevancy and importantly, reference lists were cross-checked for additional relevant studies. Results: Dysmenorrhea, chronic pelvic pain, dyspareunia, dysuria, dyschezia, and glycoprotein were found dominantly in all analyzed literature. The occurrence of endometriosis affects the functioning of women in multiple aspects of life. Endometriosis places a significant burden on teens and adult women, their families, and society as a whole. Conclusion: Combination of structured past history taking, and several biomarker level might be useful as a screening tool that easy to use and cost effective, as early diagnosis is expected to prevent further progression of endometriosis especially in adolescence.
\end{abstract}

\section{Introduction}

Endometriosis is a chronic gynaecological disorder that generally affects women of reproductive age which is characterized by implantation of endometrial tissue, both glands and stroma outside the uterus, starting from the pelvic peritoneum, ovaries, rectovaginal septum, to the pericardium, pleura, and even brain.1,2 The prevalence of endometriosis is estimated at 176 million women worldwide. ${ }^{3}$ In Indonesia, the prevalence of endometriosis still remain unclear as there has been no further research in the epidemiology of endometriosis. Data from Cipto Mangunkusumo Hospital represent more than one hundred of patients with endometriosis in 5 years. ${ }^{4}$ The clinical manifestations of endometriosis are not typical, such as chronic pelvic pain, dysmenorrhea, dyspareunia and infertility, so that this disease is difficult to detect early, causing delays in the time of diagnosis. 5 Women with endometriosis have a higher tendency to experience depressive symptoms and decreased sexual function. ${ }^{6}$ Symptoms of endometriosis contribute greatly to the 
burden of disease and add huge costs to patients through reduced economic income and productivity. ${ }^{7}$

Research shows that the initial onset of endometriosis patients begins in adolescence. ${ }^{8}$ Other studies also mention the high incidence of endometriosis that occurs during adolescence. Adolescent girls with pelvic pain, including noncyclic pain with a first-degree family history of endometriosis, should be evaluated for possible endometriosis. 9 Treatment for this age group can improve quality of life, reduce symptoms, prevent the development of more severe disease later in life and reduce the chances of future fertility problems, but further research to clarify this issue is essential. ${ }^{10}$ Until now, there is no endometriosis screening tool that can be used easily and cost effective. The gold standard for definitive diagnosis of endometriosis is visualization of the lesion during laparoscopic or laparotomy procedures. ${ }^{11}$ The high prevalence with atypical symptoms lead to long term delay in establishing the appropriate diagnosis. ${ }^{1,12}$

Early screening tools for endometriosis that easy to access and cost-effective are in high demand, especially in developing countries such as Indonesia due to limited facilities and human resources in many health center. Various studies have been developed in the search for non-invasive methods of diagnosis of endometriosis, but until now there have been no satisfying results that can be used. Further developments in the field of early endometriosis screening will greatly assist clinicians, especially general practitioners in areas with limited health facilities, in early detection of endometriosis.

\section{Methods}

Using the electronic databases, PubMed, Science Direct and Google Scholar, comprehensive literature searches were conducted with the key words (Endometriosis) AND (adolescent OR teenager) AND (pelvic pain) OR (dyschezia) OR (polyuria) OR (dysuria) OR (dysmenorrhea) OR (CA125) OR (USG). In this Review, we discuss the symptoms of endometriosis that related to adolescents, setting these topics in the context of the "early diagnosis tools" model. Full-text manuscripts published were reviewed for relevancy and importantly, reference lists were cross-checked for additional relevant studies.

\section{Results}

\section{Dysmenorrhea}

One of the most common symptoms that women with endometriosis will likely experience is dysmenorrhea. 8,9,13 There is two type of dysmenorrhea, primary and secondary. Primary dysmenorrhea is defined as the presence of recurrent, crampy, lower abdominal pain of uterine origin that occur during menstruation without other organic diseases and it represents the most common menstrual in adolescents and young women. Secondary dysmenorrhea refers to painful menses due to other pathological conditions, such as endometriosis, adenomyosis, uterine fibroids and pelvic inflammatory disease. ${ }^{14,15}$ Endometriosis is the most common cause of secondary dysmenorrhea, the pain intensity is usually vary from mild to severe. ${ }^{16,17}$ Despite the high prevalence, many women with dysmenorrhea do not report it and seek medical care, because it is accepted as a normal aspect of the menstrual cycle and therefore is tolerated.18

The most widely accepted explanation for the pathogenesis of dysmenorrhea have been identified as a hyperproduction of uterine prostaglandins (PG), particularly PGF2a and PGE2 thus resulting in increased uterine tone and high amplitude contraction. ${ }^{14,17}$ Higher circulating levels of PGF2a and PGE2 have been reported in women with dysmenorrhea compared with asymptomatic women during menstruation.15 Peritoneal fluid of women with endometriosis consist more macrophage, the inflammatory environment of this disease points out an increased production of oestrogen, which in turn will stimulates more PG through the activation of both NF$\mathrm{k}$ Band Cyclooxygenase-2 (COX-2). ${ }^{12}$ Clinical administration of exogenous PGs results in uterine contraction and often also produces the same systemic symptoms including nausea, vomiting and diarrhoea. 19

In this review the author studied six articles about endometriosis (Table 1) and found that dysmenorrhea is the most common symptoms that women with endometriosis experience from adolescent to adult. 
Case control study from Australia found that women who reported experiencing dysmenorrhea were more likely to have endometriosis develop than women reporting never or seldom experiencing pain during menstruation.20 Another study about endometriosis symptoms difference in adolescents and adults with endometriosis, turns out that all participants report the first onset of dysmenorrhea happened around 14-16 years old. The same author also conclude the sooner women seek professional help for their dysmenorrhea the sooner the diagnosis of endometriosis obtained, meanwhile adults waited almost 3 times longer between first seeing a clinician and achieving a surgical diagnosis. ${ }^{21}$ Study by Martire et al also found high percentage of dysmenorrhea among adolescent that went for USG examination, but ironically dysmenorrhea is not the chief complain for those girls, this could be because menstrual pain is commonly considered an inevitable manifestation of menses by many girls. Dysmenorrhea should be described in schools and other educational institutions as an important symptom that needs to be investigated.22

Table 1. Studies about endometriosis symptoms

\begin{tabular}{|c|c|c|c|c|c|c|}
\hline \multirow{2}{*}{ Title and Author } & \multirow{2}{*}{ Country } & \multirow{2}{*}{ Design Study } & \multicolumn{2}{|r|}{ Sample } & \multirow{2}{*}{ Variable } & \multirow{2}{*}{ Study result } \\
\hline & & & Inclusion & Exclusion & & \\
\hline \multirow{5}{*}{$\begin{array}{l}\text { Prevalence of endometriosis } \\
\text { among adolescent school girls } \\
\text { with severe dysmenorrhea: A } \\
\text { cross sectional prospective } \\
\text { study }^{8}\end{array}$} & \multirow{5}{*}{$\begin{array}{l}\text { Republic } \\
\text { of Sudan }\end{array}$} & \multirow{5}{*}{$\begin{array}{l}\text { Prospective } \\
\text { cross } \\
\text { sectional }\end{array}$} & \multirow{5}{*}{$\begin{array}{l}\text { Adolescent school } \\
\text { girls }\end{array}$} & \multirow{5}{*}{$\begin{array}{l}\text { Improved } \\
\text { analgesia }\end{array}$} & Nausea & $\mathrm{P}>0,05$ \\
\hline & & & & & Dysuria & $P>0,05$ \\
\hline & & & & & Dyschezia & $\mathrm{P}<0,05$ \\
\hline & & & & & CA125 & $\begin{array}{c}\text { Sensitivity } 78 \% \\
\text { Specificity } 89,2 \%\end{array}$ \\
\hline & & & & & Abdominal USG & $\begin{array}{c}\text { Sensitivity } 100 \% \\
\text { Specificity } 50 \%\end{array}$ \\
\hline \multirow{5}{*}{$\begin{array}{l}\text { Spectrum of symptoms in } \\
\text { women diagnosed with } \\
\text { endometriosis during } \\
\text { adolescence vs adulthood } 21\end{array}$} & \multirow{5}{*}{ USA } & \multirow{5}{*}{$\begin{array}{l}\text { Cross } \\
\text { sectional }\end{array}$} & \multirow{5}{*}{$\begin{array}{lr}\text { Adolescents } & \text { and } \\
\text { adults } & \text { with } \\
\text { surgically } & \\
\text { confirmed } & \\
\text { endometriosis } & \end{array}$} & \multirow{5}{*}{$\begin{array}{l}\text { Participants that never } \\
\text { began the baseline } \\
\text { questionnaire and no } \\
\text { operative report }\end{array}$} & Dysmenorrhea & $\mathrm{P}<0,05$ \\
\hline & & & & & Pelvic pain & $\mathrm{P}<0,05$ \\
\hline & & & & & Nausea & $\mathrm{P}<0,05$ \\
\hline & & & & & Dysuria & $\mathrm{P}<0,05$ \\
\hline & & & & & $\begin{array}{l}\text { Increased bowel } \\
\text { movement }\end{array}$ & $\mathrm{P}>0,05$ \\
\hline \multirow{6}{*}{$\begin{array}{l}\text { Adolescence and } \\
\text { endometriosis: symptoms, } \\
\text { ultrasound signs and early } \\
\text { diagnosis } 22^{22}\end{array}$} & \multirow{6}{*}{ Italy } & \multirow{6}{*}{$\begin{array}{l}\text { Retrospective } \\
\text { observational }\end{array}$} & \multirow{6}{*}{$\begin{array}{l}\text { Adolescent } \\
\text { underwent } \\
\text { transvaginal } \\
\text { transrectal } \\
\text { ultrasound }\end{array}$} & \multirow{6}{*}{$\begin{array}{l}\text { Aged }<12 \text { y and }>20 y, \\
\text { pregnant, previous pelvic } \\
\text { surgery, medical therapy } \\
\text { with estrogens and } \\
\text { progestin }\end{array}$} & Dysmenorrhea & $\mathrm{P}>0,05$ \\
\hline & & & & & Pelvic pain & $P>0,05$ \\
\hline & & & & & Dyspareunia & $\mathrm{P}<0,05$ \\
\hline & & & & & Dysuria & $\mathrm{P}>0,05$ \\
\hline & & & & & Dyschezia & $\mathrm{P}<0,05$ \\
\hline & & & & & $\begin{array}{l}\text { Heavy menstrual } \\
\text { bleeding }\end{array}$ & $\mathrm{P}>0,05$ \\
\hline \multirow{2}{*}{$\begin{array}{l}\text { Early menstrual } \\
\text { characteristics associated } \\
\text { with subsequent diagnosis of } \\
\text { endometriosis } 20\end{array}$} & \multirow{2}{*}{ Australia } & \multirow{2}{*}{ Case control } & \multirow{2}{*}{$\begin{array}{l}\text { Women aged } 18-55 \\
\text { y with and without } \\
\text { endometriosis }\end{array}$} & \multirow{2}{*}{$\begin{array}{l}\text { Menstrual characteristics } \\
\text { and symptom onset were } \\
\text { both recorded in the } 10-19 \\
\text { year age range }\end{array}$} & Dysmenorrhea & $\mathrm{P}<0,05$ \\
\hline & & & & & $\begin{array}{l}\text { Heavy menstrual } \\
\text { bleeding }\end{array}$ & $\mathrm{P}>0,05$ \\
\hline $\begin{array}{l}\text { Evaluation of CA125 in } \\
\text { relation to pain symptoms } \\
\text { among adolescents and young } \\
\text { adult women with and } \\
\text { without surgically- confirmed } \\
\text { endometriosis }\end{array}$ & USA & Case control & $\begin{array}{l}\text { Reproductive } \\
\text { women with or } \\
\text { without } \\
\text { endometriosis }\end{array}$ & $\begin{array}{l}\text { Participants that didn't } \\
\text { complete questioner }\end{array}$ & CA125 & $\mathrm{P}>0,05$ \\
\hline \multirow{3}{*}{$\begin{array}{l}\text { The Diagnostic Accuracy of } \\
\text { Combined Enolase/Cr, } \\
\text { CA125, and CA19-9 in the } \\
\text { Detection of Endometriosis } 23\end{array}$} & \multirow{3}{*}{ German } & \multirow{3}{*}{$\begin{array}{l}\text { Cross } \\
\text { sectional }\end{array}$} & \multirow{3}{*}{$\begin{array}{l}\text { Women aged } 15-45 \\
\text { y with and without } \\
\text { endometriosis }\end{array}$} & \multirow{3}{*}{$\begin{array}{l}\text { Usage of hormonal GnRH } \\
\text { last } 3 \text { months, other } \\
\text { gynaecologic disease or } \\
\text { comorbid }\end{array}$} & CA125 & $\mathrm{P}<0,05$ \\
\hline & & & & & CA $19-9$ & $\mathrm{P}<0,05$ \\
\hline & & & & & Elonase/Cr urine & $\mathrm{P}>0,05$ \\
\hline
\end{tabular}




\section{Discussion}

\section{Chronic pelvic pain}

Chronic pelvic pain (CPP) accounts for $10 \%$ of outpatient gynaecologic visits. CPP that is described as chronic, cyclic, and persistent or progressive (worsening over time) increases the likelihood of an association with endometriosis. ${ }^{24}$ Pelvic pain due to endometriosis is usually chronic (lasting $\geq 6$ months) and is associated with dysmenorrhea (in 50 to $90 \%$ of cases), dyspareunia, deep pelvic pain, and lower abdominal pain with or without back and loin pain. The pain can occur unpredictably and intermittently throughout the menstrual cycle or it can be continuous, and it can be dull, throbbing, or sharp, and exacerbated by physical activity. ${ }^{13}$ Endometriosis is a disease in which hormonally dependent, inflammatory, ectopic endometrial lesions engage the reproductive, endocrine, vascular, musculoskeletal, and neuronal systems, there are several factors that may contribute to CPP.25 Pain can be nociceptive, neuropathic and combination of those two, and endometriosis is thought to embrace all three types of pain mechanisms. ${ }^{26}$

Peripheral mechanisms in endometriosis-associated CPP are numerous with interplay between endometriotic lesions, immune system, peripheral nerve fibres in both the lesions and adjacent peritoneum and peripheral neurons. ${ }^{27}$ The mechanism of how ectopic endometrial lesions activate nervous system that caused pain has been investigated. That mechanism involves the innervation of lesions through neural sprouting of sensory and sympathetic fibers that innervate nearby blood vessels. Endometrial lesions must be vascularized to survive and grow,8 the branching of blood vessels during lesion development permits the simultaneous invasion of nerves, as the same factors that act on sprouting blood vessels act on nerve fibers. Newly sprouted nerve fibers may facilitate direct communication between the endometrial growths and the CNS, establishing a bridge for central integration of visceral sensory input. 25

CPP is one of the most common symptoms in endometriosis. An American study found that adolescent and adult with endometriosis feel acyclic pelvic pain over their life time, the pain usually last for days and CPP highly interfered their daily activity at home, school, work, reduce their productivity and daily social activity. ${ }^{21}$ The concept of offering surgery to adolescents with chronic pelvic pain to derive a histologic diagnosis of the disease is inappropriate. A complete medical, surgical, social, and family history should be obtained from patients who present with this symptom, and they should undergo a physical examination that includes a pelvic examination, allowing both early diagnosis and adequate clinical management with surgery justified only for intractable cases. ${ }^{22}$

\section{Dyspareunia, dysuria and dyschezia}

Deep dyspareunia is generally understood as pelvic pain occurring with deep penetration during intercourse or sexual activity. ${ }^{28}$ Deep dyspareunia has been reported as one of the most frequent pain symptoms caused by endometriosis. A correlation has been demonstrated between lesion site and pain type. Dyspareunia has been associated with deep lesions infiltrating the uterosacral and cardinal ligaments, the pouch of Douglas, the posterior vaginal fornix and the anterior rectal wall. Deep dyspareunia affects approximately $50 \%$ of women with endometriosis and can result in sexual dysfunction and negative impacts on relationships. ${ }^{26,29,30}$

Study by Martire et al report that most of adolescent with endometriosis that is already sexually active experience dyspareunia.22 Several studies have suggested that deep infiltrating endometriosis (DIE) lesions of the pouch of Douglas are more likely to be associated with deep dyspareunia compared with other sites. Deep dyspareunia was more frequent when DIE was found in a uterosacral ligament location than when it was not.29,31 Moreover, deep endometriotic lesions may be neurotrophic, as they have been consistently associated with higher expression of nerve growth factor (NGF) in comparison with peritoneal and ovarian implants. ${ }^{32}$

Recent studies on clinical populations have reported posterior cul-de-sac and uterosacral lesions to be positively associated with dyspareunia, bladder and peritoneal lesions with dysuria, and deep vaginal 
lesions with dyschezia. 33 As for distinct anatomic locations, severity of dyschezia was significantly greater in posterior vaginal wall, rectovaginal septum, and anterior rectal wall DIE, whereas mean VAS score was not significantly different in patients with uterosacral ligament involvement compared with control groups. ${ }^{34}$ Pain remains the most important symptom for many women with endometriosis. Inflammation, peripheral and central pain generators, endocrine changes and structural alterations in the periphery and in the CNS may all contribute to endometriosis associated pain. 25,27

\section{Glycoproteins}

The discovery of a sufficiently sensitive and specific biomarker for nonsurgical detection of endometriosis would permit early diagnosis as well as prevent harmful sequelae of the disease. ${ }^{23}$ Cancer Antigen 125 (CA-125) is a high molecular-weight glycoprotein normally expressed on tissues derived from the coelomic and mullerian epithelia including the uterus endometrium. CA-125 has been reported to be elevated in endometriosis patients and is the most commonly described, extensively studied endometriosis biomarker to date. ${ }^{35} \mathrm{CA}-125$ is often used in the diagnosis of ovarian cancer, but it can also be altered in endometriosis. ${ }^{36}$ Although lacking both specificity and sensitivity for this pathology, the most representative glycoprotein used as a biomarker for endometriosis is CA-125. However, the simultaneous measurement of CA-125 with other molecules and their combination showed different sensitivities and specificities for endometriosis. ${ }^{12} \mathrm{CA}-125$ seems to be hampered as a single clinically reliable diagnosis biomarker of endometriosis.

CA-19-9, also a tumor marker used in the investigation of ovarian cancer, has been tested in patients with endometriosis, and only a few studies detected a tendency of elevated levels in patients with endometriosis. ${ }^{36}$ The cut off thresholds of CA-199 used to detect endometriosis in various studies are diverse, ranging from $>7.5$ to $>37.0 \mathrm{IU} / \mathrm{mL} .{ }^{37}$ A review of the published literature suggests that an extremely high CA125 level combined with a high CA19-9 level is a possible indicator of endometriosis. Study by Rokhgireh et al observed that combined CA-125 with CA-19-9 and enolase-1 as a biomarker for endometriosis, this combination gives a sensitivity of $65 \%$ and specificity of $66,6 \%$ for endometriosis. ${ }^{23}$ The present study revealed that combined biomarkers possess greater sensitivity and specificity, and greater diagnostic power for the detection of endometriosis.

Retrospective study by Chen et al found the combination of haemoglobin, CA125, CA19-9 and H4 show a sensitivity of $85.4 \%$, a specificity of $78.83 \%$, and an area under the curve of 0.900, which was significantly higher than that of the individual index in endometriosis diagnosis. ${ }^{38}$ Meta analysis has been conducted to study the diagnostic value of combined CA125 and CA19-9 as biomarker to diagnose endometriosis, in accordance with finding of others, Shen et al confirmed higher value of CA125 and CA199 in women with endometriosis compare to healthy women. ${ }^{39}$ This conclude that endometriosis is highly associated with elevated serum CA125 and CA19-9, and the combination of this two may represent useful biomarker for the non-invasive diagnosis of endometriosis.

\section{Conclusion}

The occurrence of endometriosis affects the functioning of women in multiple aspects of life. Endometriosis places a significant burden on teens and adult women, their families, and society as a whole. Despite decades of research, there are still major challenges in the diagnosis and treatment of endometriosis. Recent literature on adolescent endometriosis has focused on the development of a clinical profile of adolescents with pelvic pain who are likely to be diagnosed with the disease. The importance of understanding patients is crucial. Endometriosis in adolescents is a disease to be considered as an important differential diagnosis in pelvic pain and adnexal cysts, especially among those with pain resistant to the use of commonly used medication. Medical professional should be aware of the signs and symptoms to make an early diagnosis, thereby preventing progression of the disease and providing the 
most appropriate treatment for each patient. Combination of structured past history taking, and several biomarker level might be useful as a screening tools that easy to use and cost effective, as early diagnosis is expected to prevent further progression of endometriosis especially in adolescence.

\section{References}

1. Giudice LC, Kao LC. Endometriosis. Lancet. 2004; 364(9447): 1789-99.

2. Rogers PAW, D'Hooghe TM, Fazleabas A, Giudice LC, Montgomery GW, Petraglia F, et al. Defining future directions for endometriosis research: Workshop report from the 2011 World Congress of Endometriosis in Montpellier, France. Reprod Sci. 2013; 20(5): 483-99.

3. David Adamson G, Kennedy S, Hummelshoj L. Creating solutions in endometriosis: Global collaboration through the World Endometriosis Research Foundation. J Endometr. 2010; 2(1): 3-6.

4. Puspasari B, Baziad A, Hestiantoro A. Karakteristik Pasien Endometriosis di Rumah Sakit Dr. Cipto Mangunkusumo. Indones $\mathrm{J}$ Obs Gynecol. 2007; 31(2):7 3-8.

5. Johnson NP, Hummelshoj L, Adamson GD, Keckstein J, Taylor HS, Abrao MS, et al. World endometriosis society consensus on the classification of endometriosis. Hum Reprod. 2017; 32(2): 315-24.

6. Mińko A, Turoń-Skrzypińska A, Rył A, Bargiel P, Hilicka Z, Michalczyk $\mathrm{K}$, et al. Endometriosis - a multifaceted problem of a modern woman. Int $\mathrm{J}$ Environ Res Public Health. 2021; 18(15).

7. Simoens S, Dunselman G, Dirksen C, Hummelshoj L, Bokor A, Brandes I, et al. The burden of endometriosis: Costs and quality of life of women with endometriosis and treated in referral centres. Hum Reprod. 2012; 27(5): 1292-9.

8. Ragab A, Shams M, Badawy A, Alsammani MA, Ragab A. Prevalence of endometriosis among adolescent school girls with severe dysmenorrhea: A cross sectional prospective study. 2015; 9(3).

9. Dowlut-mcelroy T, Strickland JL. Endometriosis in adolescents. 2017; 1-4.

10. Johnson NP, Hummelshoj L. Consensus on current management of endometriosis. Hum Reprod. 2013; 28(6): 1552-68.

11. Kennedy S, Bergqvist A, Chapron C, D'Hooghe $\mathrm{T}$, Dunselman G, Greb $\mathrm{R}$, et al. ESHRE guideline for the diagnosis and treatment of endometriosis. Hum Reprod. 2005; 20(10): 2698-704.

12. Anastasiu CV, Moga MA, Neculau AE, Bălan A, Scârneciu I, Dragomir RM, et al. Biomarkers for the noninvasive diagnosis of endometriosis: State of the art and future perspectives. Int $\mathrm{J}$ Mol Sci. 2020; 21(5): 1-24.

13. Giudice LC. Clinical Practice: Endometriosis. N Engl J Med [Internet]. 2010 Jun 24; 362(25):2389-98. Available from: http: / / www.nejm.org/doi/abs/10.1056/NEJ Mcp 1000274

14. Clemenza S, Vannuccini S, Capezzuoli T, Meleca CI, Pampaloni F, Petraglia F. Is primary dysmenorrhea a precursor of future endometriosis development? Gynecol Endocrinol [Internet]. 2021; 37(4): 287-93. Available from: https://doi.org/10.1080/09513590.2021.187 8134

15. Iacovides S, Avidon I, Baker FC. What we know about primary dysmenorrhea today: A critical review. Hum Reprod Update. 2015; 21(6): 76278.

16. De Paula Andres M, Podgaec S, Carreiro KB, Baracat EC. Endometriosis is an important cause of pelvic pain in adolescence. Rev Assoc Med Bras. 2014; 60(6): 560-4.

17. Petraglia F, Bernardi M, Lazzeri L, Perelli F, Reis FM. Dysmenorrhea and related disorders. F1000Research. 2017; 6(0): 1-7.

18. Subasinghe AK, Happo L, Jayasinghe YL, Garland SM, Gorelik A, Wark JD. Prevalence 
and severity of dysmenorrhoea, and management options reported by young Australian women. Aust Fam Physician. 2016; 45(11): 829-34.

19. Sachedina A, Todd N. Dysmenorrhea, endometriosis and chronic pelvic pain in adolescents. JCRPE J Clin Res Pediatr Endocrinol. 2020; 12(Suppl 1): 7-17.

20. Treloar SA, Bell TA, Nagle CM, Purdie DM, Green AC. Early menstrual characteristics associated with subsequent diagnosis of endometriosis. YMOB [Internet]. 2010; 202(6): 534.e1-534.e6. Available from: http:/ /dx.doi.org/10.1016/j.ajog.2009.10.85 7

21. Divasta AD, Sm AFV, Laufer MR, Scd SAM. Spectrum of symptoms in women diagnosed with endometriosis during adolescence vs adulthood. Am J Obstet Gynecol [Internet]. 2018; 218(3): 324.e1-324.e11. Available from: https://doi.org/10.1016/j.ajog.2017.12.007

22. Martire FG, Lazzeri L, Ph D, Conway F, Siciliano T. Adolescence and endometriosis: symptoms, ultrasound signs and early diagnosis. Fertil Steril [Internet]. 2019; Available from: https://doi.org/10.1016/j.fertnstert.2020.06. 012

23. Rokhgireh S, Mehdizadeh Kashi A, Chaichian S, Delbandi AA, Allahqoli L, Ahmadi-Pishkuhi $\mathrm{M}$, et al. The Diagnostic Accuracy of Combined Enolase/Cr, CA125, and CA19-9 in the Detection of Endometriosis. Biomed Res Int. 2020; 2020.

24. Agarwal SK, Chapron C, Giudice LC, Laufer MR, Leyland N, Missmer SA, et al. Clinical diagnosis of endometriosis: a call to action. Am J Obstet Gynecol [Internet]. 2019 Apr; 220(4): 354.e1-354.e12. Available from: doi: 10.1016/j.ajog.2018.12.039

25. Aredo J, Heyrana K, Karp B, Shah J, Stratton P. Relating Chronic Pelvic Pain and Endometriosis to Signs of Sensitization and Myofascial Pain and Dysfunction. Semin
Reprod Med [Internet]. 2017 Jan 3; 35(01): 088-97. Available from: http://www.thiemeconnect.de/DOI/DOI?10.1055/s-0036-

1597123

26. Vercellini P, Viganò P, Somigliana E, Fedele L. Endometriosis: Pathogenesis and treatment. Nat Rev Endocrinol [Internet]. 2014; 10(5): 261-75. Available from: http://dx.doi.org/10.1038/nrendo.2013.255

27. Morotti M, Vincent K, Becker CM. Mechanisms of pain in endometriosis. Eur J Obstet Gynecol Reprod Biol [Internet]. 2017; 209: 8-13. Available from: http://dx.doi.org/10.1016/j.ejogrb.2016.07.4 97

28. Ferrero S, Ragni N, Remorgida V. Deep dyspareunia: Causes, treatments, and results. Curr Opin Obstet Gynecol. 2008; 20(4): 394-9.

29. Fauconnier A, Chapron C, Dubuisson JB, Vieira M, Dousset B, Bréart G. Relation between pain symptoms and the anatomic location of deep infiltrating endometriosis. Fertil Steril. 2002; 78(4): 719-26.

30. Orr NL, Noga H, Williams C, Allaire C, Bedaiwy MA, Lisonkova S, et al. Deep Dyspareunia in Endometriosis: Role of the Bladder and Pelvic Floor. J Sex Med [Internet]. 2018; 15(8): 115866. Available from: https://doi.org/10.1016/j.jsxm.2018.06.007

31. Yong PJ. Deep dyspareunia in endometriosis: A proposed framework based on pain mechanisms and genito-pelvic pain penetration disorder. Sex Med Rev [Internet]. 2017; 5(4): 495-507. Available from: http://dx.doi.org/10.1016/j.sxmr.2017.06.00 5

32. Anaf V, Simon P, El Nakadi I, Fayt I, Simonart $T$, Buxant $F$, et al. Hyperalgesia, nerve infiltration and nerve growth factor expression in deep adenomyotic nodules, peritoneal and ovarian endometriosis. Hum Reprod. 2002; 17(7): 1895-900.

33. Schliep KC, Mumford SL, Peterson CM, Chen Z, Johnstone EB, Sharp HT, et al. Pain 
typology and incident endometriosis. Hum Reprod. 2015; 30(10): 2427-38.

34. Seracchioli R, Mabrouk M, Guerrini M, Manuzzi L, Savelli L, Frascà C, et al. Dyschezia and posterior deep infiltrating endometriosis: Analysis of 360 cases. J Minim Invasive Gynecol. 2008; 15(6): 695-9.

35. Sasamoto N, DePari M, Vitonis AF, Laufer MR, Missmer SA, Shafrir AL, et al. Evaluation of CA125 in relation to pain symptoms among adolescents and young adult women with and without surgically-confirmed endometriosis. PLoS One [Internet]. 2020;15(8 August): 1-13. Available

from: http:/ /dx.doi.org/10.1371/journal.pone.0238 043

36. Coutinho LM, Ferreira MC, Rocha ALL, Carneiro MM, Reis FM. New biomarkers in endometriosis [Internet]. 1st ed. Vol. 89, Advances in Clinical Chemistry. Elsevier Inc.; 2019; 59-77. Available from: http://dx.doi.org/10.1016/bs.acc.2018.12.00 2

37. Tian Z, Chang XH, Zhao Y, Zhu HL. Current biomarkers for the detection of endometriosis. Chin Med J (Engl). 2020; 133(19): 2346-52.

38. Chen T, Wei L, Leng T, Gao F. The diagnostic value of the combination of hemoglobin, CA199, CA125, and HE4 in endometriosis. 2021; (April): 1-8.

39. Shen A, Xu S, Ma Y, Guo H, Li C, Yang C, et al. Diagnostic value of serum in endometriosis: A meta-analysis. 2015; (7). 